\title{
Comparison of the Financial Performance between Square Pharmaceuticals Limited and Beximco Pharmaceuticals Limited: DuPont Analysis
}

Mohammad Jafaur Ahamed

Associate Professor (Accounting), Open School, Bangladesh Open University, Gazipur, BANGLADESH

Corresponding Contact:

Email: jafaur@yahoo.com

\begin{abstract}
The study attempts to make a comparison of financial strength between Square Pharmaceuticals Limited (SQPL) and Beximco Pharmaceuticals Limited (BXPL) by using the technique of DuPont analysis. Pharmaceuticals are selected here based on a purposive sampling method with the criteria of convenience in annual reports availability. The research is based on secondary data available in annual reports of FY 2018-19 of the selected companies. The study reveals that in comparison with BXPL, SQPL has been utilizing its owners' funds more profitably, doing operational activities more efficiently, and earning enough returns for its owners. Beximco Pharmaceuticals Ltd. applies aggressive debt-equity policy, which does not magnify its earnings due to the lack of its sufficient rate of returns in comparison with interest burden, lack of core operational efficiency, and underutilization of resources. At the same time, leverage helps the SQPL to fuel the growth of the business. There is a good thing that the two companies have almost the same amount of tax burden ratio, although EBIT is highly differing between the companies. The study suggests that to achieve a high RoE, Beximco Pharmaceuticals Company must reduce its interest expenses, utilize its full capacities, and increase its assets turnover. Besides, both the pharmaceuticals are suggested to focus on the inflation-adjusted financial items in its annual reports. The study has operated only on DuPont analysis. Thus further research is recommended to conduct focusing on others such as common-size analysis, comparative analysis, trend analysis, and ratio analysis, etc. to investigate the financial health of pharmaceutical companies.
\end{abstract}

Key Words: Pharmaceuticals company, DuPont analysis, Operating efficiency, Bangladesh 


\section{INTRODUCTION}

Management, owners, creditors, investors, and others evaluate the financial performance of the firm by using the information contained in that firm's annual reports. Financial performance is a yardstick of how feasible, stable, profitable, liquid-able, and solvent of a business firm. There are different techniques such as trend analysis, common-size analysis, ratio analysis, DuPont analysis, etc. we usually apply to measure the financial performance of the business at many aspects of its profitability, liquidity, and solvency. The DuPont analysis is a tool to evaluate the operating efficiency of a firm. According to Sheela and Karthikeyan (2012), an engineer at DuPont Corporation in America, who was responsible for handling the finances of the company, developed the DuPont system in 1918. The engineer noticed that the product of two often-computed ratios, net profit margin and total asset turnover, equals a return on assets (RoA). The smoothness of RoA being affected by a profitability measure and an efficiency measure led to the DuPont method becoming a widely used tool of financial analysis (Liesz, 2002). This model is a commonly used tool for assessing and understanding the elements of profitability (Barry et al., 2000). Like the RoA, return on equity (RoE) can be segmented into parts to inform us why the percentage of return varies from year to year or why two firms' returns on equity differ. The RoE is identical to return on total assets multiplied by the equity multiplier. The net profit margin of a firm is the product of its earnings before interest and taxes (EBIT), tax burden, and interest burden. The Pharmaceuticals sector contributed 1.83\% of the GDP in 2017-18 (Source: Bangladesh Bureau of Statistics). At present, 257 licensed pharmaceutical companies exist in Bangladesh, among which 150 are functional. Although the market has several competitors, the top 15 to 20 pharmaceuticals control the domestic market. According to IMS (2018), the top 25 pharmaceutical companies account for $90 \%$ of market share, out of which, Square Pharmaceuticals leading the way with $17.0 \%$ market share while Beximco Pharmaceuticals with $8.3 \%$. A Pharmaceuticals company's RoE may differ from one year to the next, or from a competitor's, because of differences in its profit margin, asset turnover, or leverage. The DuPont model visualizing the financial information related to profit margin, asset turnover, or debt-equity ratio, and is a tool for assisting stakeholders in understanding how operating, financing, and investment decisions impact financial performance. Based on the importance of DuPont Model, the study attempts to assess the financial health of two dominating pharmaceutical companies in Bangladesh, namely, Square Pharmaceuticals Limited and Beximco Pharmaceuticals Limited.

\section{OVERVIEW OF THE COMPANIES}

Square Pharmaceuticals Limited (SQPL) is a big pharmaceuticals company in Bangladesh, also the pioneer and a trusted name in the pharmaceuticals sector of the country. This indigenous concern was established in 1958 as a partnership firm under the leadership of Late Samson H. Chowdhury. In 1964, it was converted into a Private Limited Company, then in 1991; it transferred into a public limited company, and become a publicly listed company in Dhaka Stock Exchange Limited in 1995. It has explored its range of business towards the path of the global market. It pioneered exports of health care products from Bangladesh in 1987 and has been exporting antibiotics and other pharmaceutical products (Source: SQPL's annual report of FY 2018-19). Square Pharmaceuticals is to emphasize the quality of product, process, and services leading to the growth of the company ensured with good governance practices. The company always concern about the protection of shareholders' capital as well as the highest return and growth of their assets. Besides, it strives for the fulfillment of their responsibilities or obligations to the employees, societies, and government. Beximco 
Pharmaceuticals Limited (BXPL) is also a focal manufacturer and exporter of drugs or other preparations for the treatments in Bangladesh. Established in 1976, the company commenced its activities by importing health care products from abroad and selling them in the local market. In 1980, BXPL began manufacturing these products under the licensing arrangement and started its formulation brands in 1983. From the beginning, Beximco Pharma has grown upwards, and today it has become a leading global generic drug company from the Asian region. The company has achieved the national export gold trophy five times. It remains the only company in the country to win the highly prestigious SCRIP award as the best pharmaceuticals company in the market. It also has the unique feature as the only Bangladeshi company listed on the Alternative Investment Market (AIM) of the London Stock Exchange. The company currently employs more than 4,500 employees, including doctors, pharmacists, engineers, chemists, accountants, business graduates, and other white-collar professionals (Source: BXPL's annual report of FY 2018-19).

\section{NEED FOR THE STUDY}

The DuPont chart of financial analysis can be used to make a financial strategy for a business. It is a useful model in presenting both an overview and a focus on the financial strength of an organization. The model is worked as a parameter in the process by directing the analyst or decision-makers towards the significant areas of opportunities and threats in the financial statements. This analysis helps to isolate the causes of strength and weakness in the firm's performance. Moreover, it has been observed that although a high-profit margin is a yardstick of satisfactory performance, a low margin does not indicate a lower rate of return on investments if a firm has higher investment or assets turnover. Therefore, the overall operating efficiency, i.e. the earnings power of a firm can be judged based on a combination of the two. DuPont system regards as a compass in the case of taking the operating and investing decision as well as the financing and tax-related conclusions (Yang and Yoon, 2005). Thus, the study would contribute to assessing the overall financial performance of pharmaceuticals in Bangladesh. Although many research studies were done on financial performance evaluation, as of now, few studies have done on DuPont analysis even remains unexplored until now. These are the thinking forces to choose this topic as a research study and hope that it would be helpful for the concerned policy-makers of pharmaceuticals, shareholders of related concerns, researchers, economic planners, government, and other interested parties.

\section{Research Question}

What are the values of the items of the DuPont Chart, and what do these tell us about the financial health of SQPL and BXPL?

\section{REVIEW ON RELATED LITERATURE}

Many studies were done on performance analysis through the different techniques of analysis. Still, a few studies were operated on performance evaluation by applying DuPont analysis -those are reviewed here focusing on their findings and recommendations. Mishelle (2016) had performed a research on DuPont analysis of the top three food industries, namely Tiger Brands, Pioneer Foods, and RCI, in South Africa. To achieve the objectives of his research, RoE and RoA had been calculated by applying the DuPont Chart. A detailed financial analysis of all three companies using the DuPont system, the researcher found that investing in Tiger Brands would generate a higher return to shareholders than Pioneer Foods or RCI. McGowan and Stambaugh (2012) conducted a study on financial analysis of 
commercial banks using an extension of the DuPont systems during the period of 2003 to 2010. The authors opined that the DuPont system of analysis is based on return on equity, with the components of this ratio being the net profit, the total asset turnover, and the equity multiplier. Their analysis demonstrates that return on assets for Monarch Bank derives primarily from return on investments. That is, $86 \%$ of the investment-weighted return on assets for Monarch Bank derives from return on loans. According to Soliman (2008), a change in asset turnover is positively related to future changes in earnings, and he goes on to discuss the extent to which competitive forces differently affect the profitability of a firm noting that large profit margins draw new entrants into the market place or result in existing rivals imitating the new idea. Besides, he found that competition might be less threatening to efficient deployment of assets. If production processes are efficient, it makes it difficult to imitate another firm's ideas due to the some cost factors involved. This is an attempt to isolate the causes of strength and weakness in the firm's performance. Bodie et al. (2004) had opined in his text that DuPont focuses on the expense control, assets utilization, and debt utilization capacity of the firm. Tushar (2017) operated research on return on equity analysis using DuPont model for three firms in the beverages industry, namely Pepsi, Coke, and Lehar. By observing the companies DuPont Chart, the author can be concluded that: Coke is taking advantage of its brand name to sell products at a premium, which leads to lower asset turnovers but higher profit margins. Pepsi is playing a balanced game, maintaining a decent asset turnover and profit margin. It has the brand name to add a premium, but it has efficiently balanced turnovers with it. Lehar is a low-cost producer-selling product as a commodity. It focuses on high asset turnover on lower margins, but the market share owned by Lehar is not favorable for this kind of strategy to succeed. Rogova (2014) opined that the DuPont model properly disclosed the elements of efficiency which had, in turn, impact the investment appeal of Russian oil-extracting companies. The author found that a strong benefit of RoE was the possibility of its disaggregation into different profitability ratios, with RoE indicating profitability and efficiency from the stakeholders' point of view.

\section{Methodology OF THE Study}

The sample of this study consists of the top two pharmaceutical companies listed in stock markets of Bangladesh, namely, Square Pharmaceuticals Limited and Beximco Pharmaceuticals Limited, which are selected based on a purposive sampling method with the criteria of convenience in annual reports availability. The research is based on secondary data available in the financial reports of FY 2018-19 of the selected companies. Websites of the sample companies were searched to obtain copies of annual reports, and some other relevant local and foreign journals' websites were searched for other details through the Google search engine (www.google.com). The paper analyzed the comparative performance of the selected pharmaceuticals using the elements of the DuPont Model. The values of the ratios are presented through the tables and graphs constructed by using Microsoft Excel.

\section{Objectives OF The Study}

The objectives of the study are:

i. To calculate the value of basic elements of the DuPont Analysis Model of Square Pharmaceuticals Limited and Beximco Pharmaceuticals Limited;

ii. To compare the financial performance between the Square Pharmaceuticals Limited and Beximco Pharmaceuticals Limited using DuPont Analysis Model; 
iii. Provide some suggestions for the improvement of the financial performance of selected pharmaceuticals.

\section{FINDINGS AND ANALYSIS}

DuPont decomposition of return on equity (RoE) identifies the operators of a company's RoE in terms of EBIT margin, interest burden, tax burden, total asset turnover ratio, and financial leverage ratio. To achieve satisfactory RoE, a company must enhance its EBIT margin, control its interest expenses, increase its asset utilization, and modify its debt-servicing capacity. Based on secondary data and DuPont analysis, the summary of findings of the study is noted below:

Figure 1: Basic Elements of the DuPont Analysis Model of Square Pharmaceuticals Ltd.

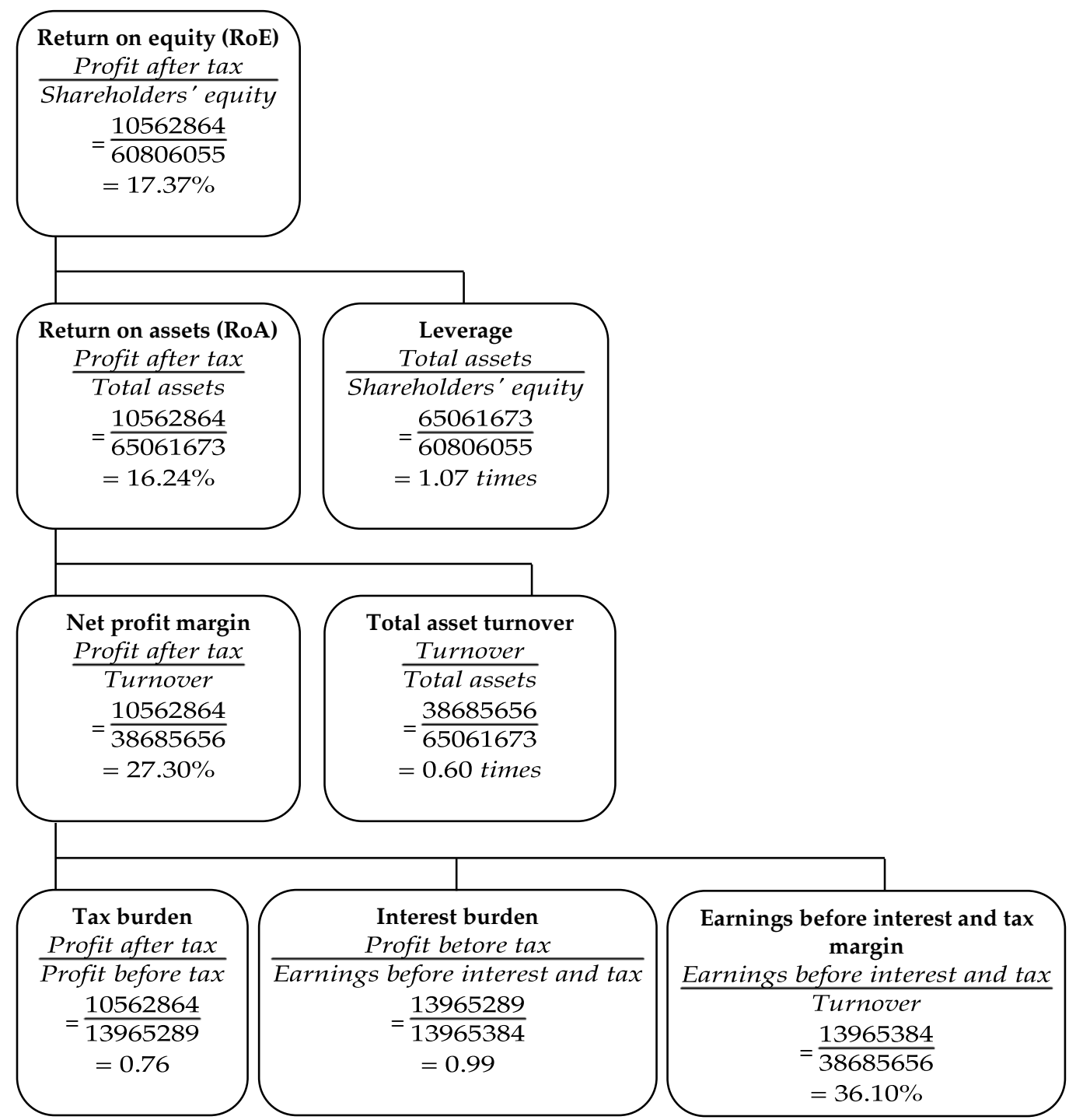

Source: Annual report of Square Pharmaceuticals Limited- FY 2018-19; Note: Figures Tk. in `000 
Figure 2: Extended DuPont Model for Square Pharmaceuticals Ltd.

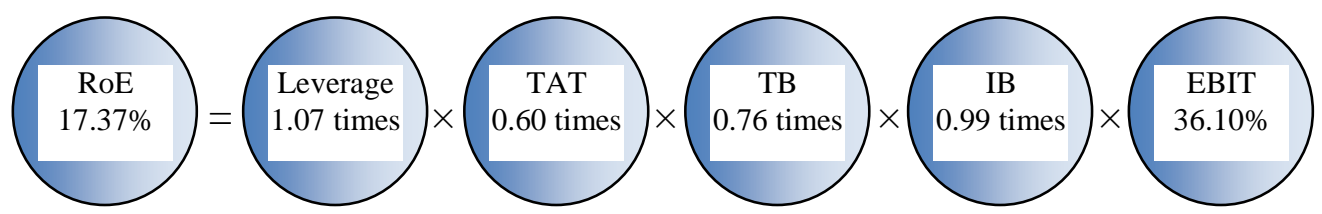

Note: Fractional Error $=0.07$. RoE=Return on equity, TAT $=$ Total assets turnover, $\mathrm{TB}=\mathrm{Tax}$ burden, $\mathrm{IB}=$ Interest Burden, EBIT = Earnings before interest and taxes.

Figure 3: Basic Elements of the DuPont Analysis Model of Beximco Pharmaceuticals Ltd.

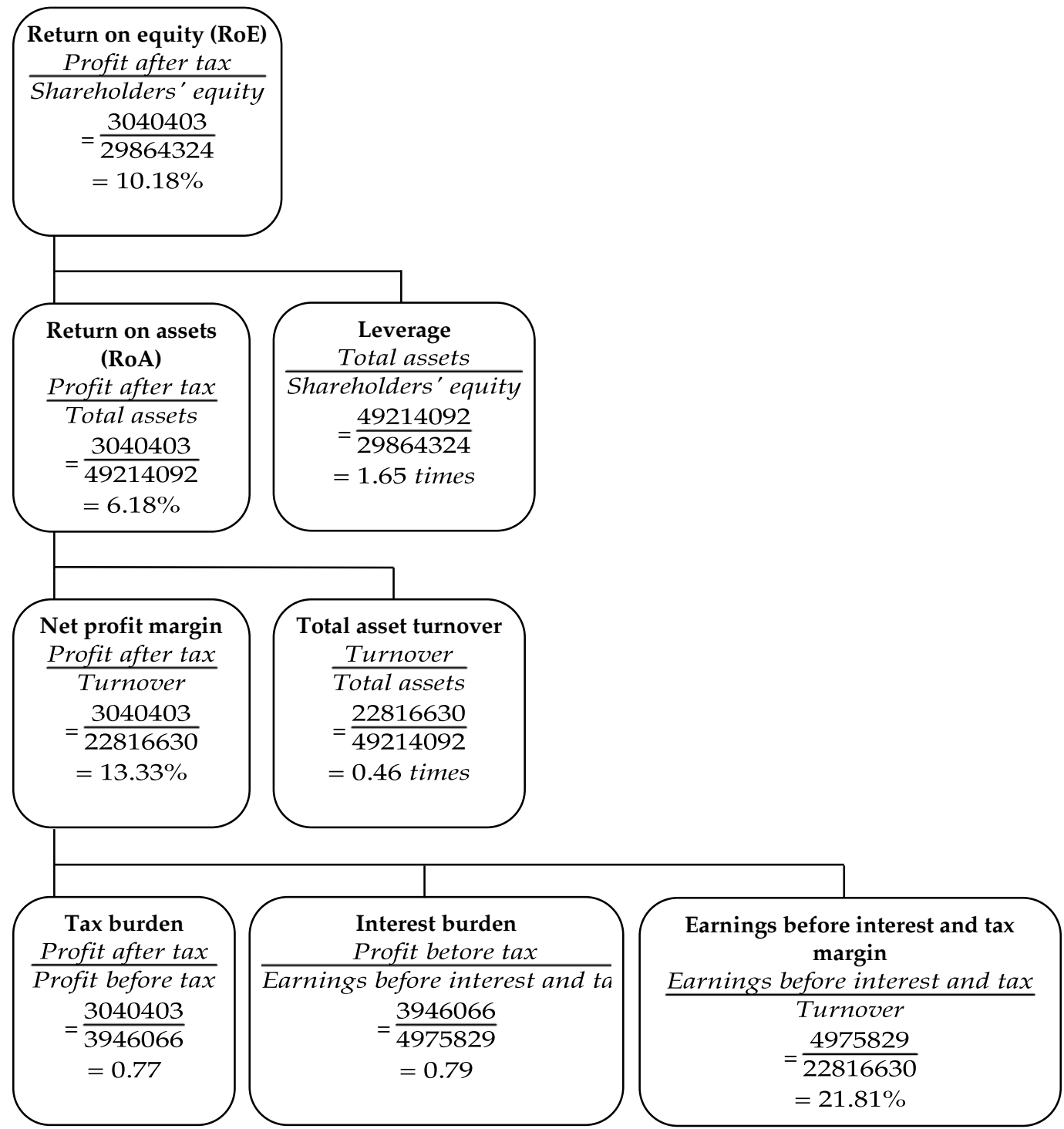

Source: Annual report of Beximco Pharmaceuticals Limited- FY 2018-19; Note: Figures Tk. in `000 
Figure 4: Extended DuPont Model for Beximco Pharmaceuticals Ltd.

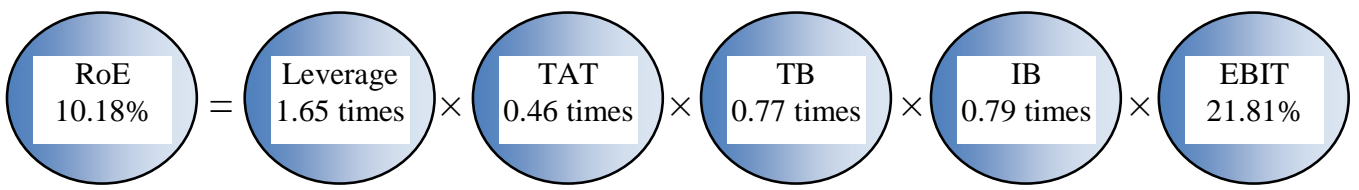

Note: Fractional Error $=0.11$. RoE=Return on equity, $\mathrm{TAT}=$ Total assets turnover, $\mathrm{TB}=\mathrm{Tax}$ burden, IB =Interest Burden, EBIT= Earnings before interest and taxes.

Figure 5: Comparison of Decomposed RoE (Express in Percentage)

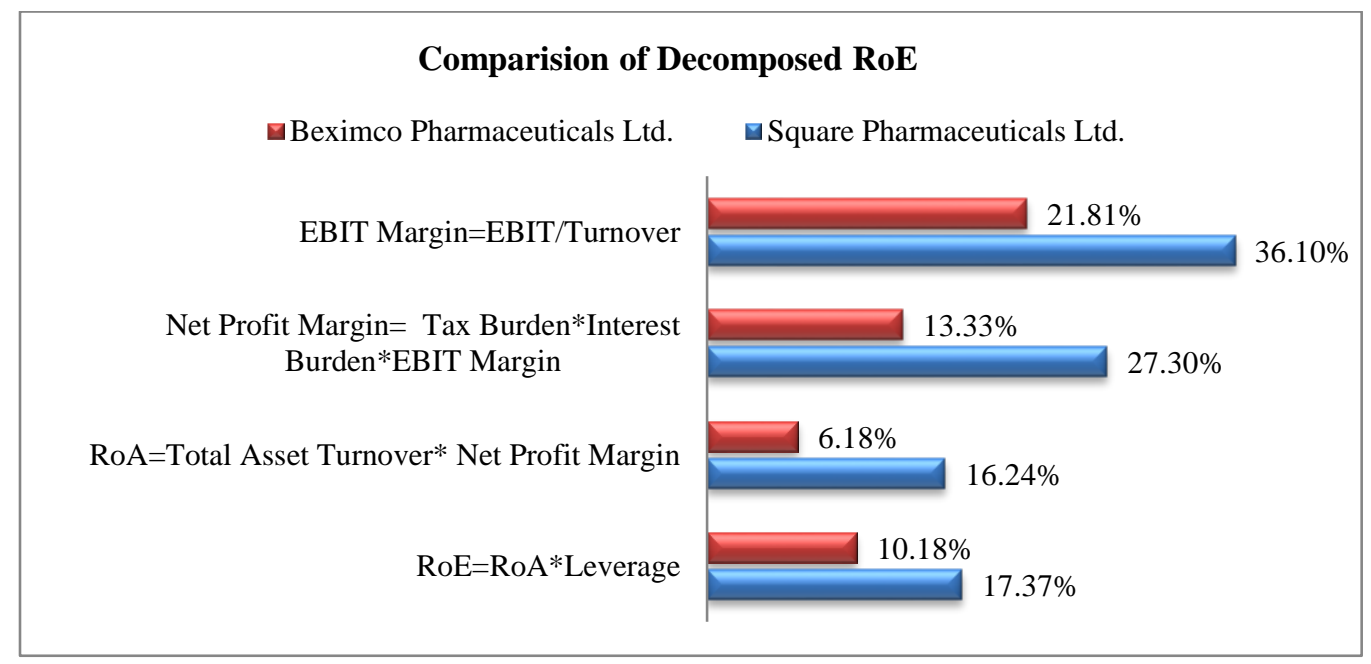

Source: Annual reports of the selected companies- FY 2018-19

Figure 6: Comparison of Decomposed RoE (Express in Times)

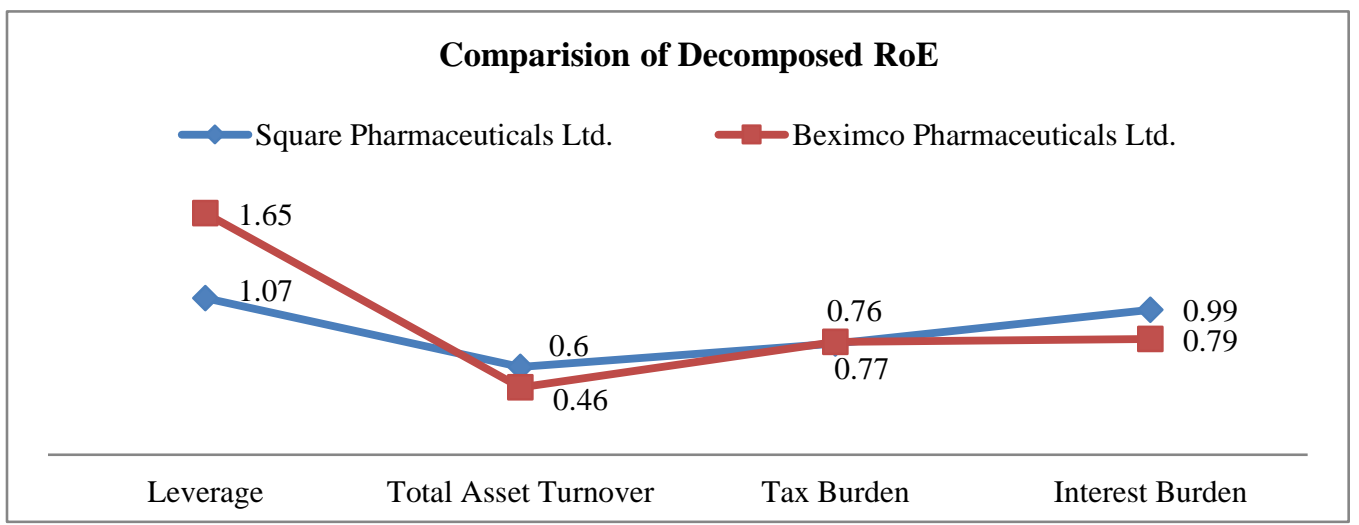

Source: Annual reports of the selected companies- FY 2018-19

Return on Equity: The above figures show that Square Pharmaceuticals Limited's return on equity (RoE) is $17.3 \%$, whereas the rate for Beximco Pharmaceuticals Limited's is $10.18 \%$. This ratio reveals that the management of SQPL has been utilized the owner's fund more profitably 
than BXPL. Besides, this rate of RoE shows that the management of SQPL is growing the company's value at an acceptable rate than BXPL.

Return on Assets: SQPL's has a higher Return on Assets (RoA) i.e., 16.24\% than that of BXPL $(6.18 \%)$, which correctly reports us the operating efficiency of SQPL is better than BXPL.

Net Profit Margin: The Net Profit (NP) Margin of SQPL is more than double $(27.30 \%)$ in comparison with BXPL (13.33\%), which ensures that SQPL earns an adequate return to the owners as well as enable to withstand in adverse economic conditions when selling price of products is declining, cost of production is rising, or demand for the product is falling.

Earnings before Interest and Tax: EBIT margin of SQPL $(36.10 \%)$ is higher than that of BXPL $(21.81 \%)$, which indicates that Square Pharmaceuticals Company has the more ability to generate enough earnings from operations to be profitable, pay down tax and interest than Beximco Pharmaceuticals Company.

Financial Leverage: Financial leverage of SQPL's is 1.07 times, while BXPL's has 1.65 times. It indicates that BXPL has been aggressive in financing its growth with debt. This aggressive debt-equity policy for BXPL is not satisfactory, because it can't earn an advantageous rate of return than the interest rate on its loan. On the other side, SQPL's financial leverage magnifies its growth, because it earns a more lucrative rate of returns than its interest burden. We can conclude here that, debt helps the SQPL to fuel growth, while it makes the BXPL as risky or chances of a defaulter.

Total Assets Turnover: Square Pharmaceuticals Limited Company has used its total assets 0.60 times over the year to generate its returns, whereas the figure for Beximco Pharmaceuticals Limited's is 0.46 times. This higher asset turnover ratio of SQPL indicates that the more efficient the management and utilization of the assets. In contrast, the low turnover ratio of BXPL indicates of under-utilization of available resources and the presence of idle capacity.

Tax Burden: Tax burden element in DuPont chart is the ratio of a company's earnings after taxes to its earnings before taxes. It shows the proportion of earnings before taxes (EBT) that has left after income tax charge. Tax burden earning of SQPL is 0.76 times of its EBIT in comparison, the figure is 0.77 times for BXPL, which indicates that both the companies have almost the same ratios of the tax burden and they are keeping about the same percentages of its pretax income, which will result in their RoE.

Interest Burden: Interest burden is the ratio of earnings before taxes (EBT) to earnings before interest and taxes (EBIT). The above figures show that after the deduction of interest expense, SQPL has leftover 0.99 times of its EBIT to achieve a satisfactory RoE. Besides, BXPL has leftover 0.79 times of its EBIT, which implies that BXPL has the poor capability to earn more operating profit, and it suffers more loan burden in comparison with the SQPL.

\section{Conclusions and Recommendations}

The DuPont model of financial analysis provides a technique for the firm to monitor its overall earnings performance. It can be used to find out the strong and weak points in the financial health of the firm. This study attempts to measure the financial performance of the top two Pharmaceutical Industries in Bangladesh. SQPL has been utilizing its owner's fund more profitably, doing operational activities more efficiently, and earning enough returns for its owners. Beximco Pharmaceuticals Ltd. applies aggressive debt-equity policy, which does not magnify its revenue due to the lack of its sufficient rate of returns compare with interest 
burden and under-utilization of resources, in contrast, leverage helps the SQPL to fuel the growth of the business. There is a good thing that the two companies have almost the same amount of tax burden, but the EBIT of SQPL is higher than BXPL. As a result, Beximco Pharmaceuticals suffers the interest coverage, maybe the possibility of default to make interest payments, and that the business is at risk of increases in interest rates. To overcome such situations as well as to achieve high RoE, Beximco Pharmaceuticals should follow the beneath listed suggestions:

- Beximco Pharmaceuticals must reduce its interest expenses and increase its core operational efficiency such that its EBIT ratio is high.

- $\quad$ BXPL should minimize its debt amount because too much debt can be dangerous for a company and its investors.

- BXPL should concentrate on generating a higher rate of return than its interest rate such that leverage magnifies its returns.

The study is restricted to the accounting data generated in the sample companies' annual reports during the year 2018-19. Besides, in some cases, sample companies do not disclose the inflation-adjusted financial items in their annual reports. Also, few fractional errors have occurred in the study at the time of ratios calculation; the research has applied only one technique of financial analysis. Therefore, a further study focusing on other tools, including common-size analysis, comparative analysis, trend analysis, and ratio analysis, is recommended to investigate the financial performance of pharmaceuticals companies.

\section{REFERENCES}

Barry, P. J., Ellinger, P. N., Hopkin, J. A. \& Baker, C. B. (2000). Financial Management in Agriculture, 6th ed. Danville, IL: Interstate Publishers, 2000, 678 pp. DOI https://doi.org/10.1111/1467$\underline{8276 . t 01-1-00102}$

Bodie, Z., Kane, A., \& Marcus, A. J. (2004). Essentials of Investments, 5th ed. McGraw-Hill Irwin. pp. 458-459. ISBN 0-07-251077-3

IMS (2018). Intercontinental Medical Statistics, https:/ / www.imshealth.com/

Liesz, J. T. (2002). Really Modified Du Pont Analysis: Five Ways to Improve Return on Equity. Unpublished research work. Available at: http://citeseerx.ist.psu.edu/.

McGowan, C. B., \& Stambaugh, A. R. (2012). Using disaggregated return on assets to conduct a financial analysis of a commercial bank using an extension of the DuPont system of financial analysis. Accounting and Finance Research, 1(1), 152-161

Mishelle, D. (2016). Using DuPont analysis to assess the financial performance of the top three JSE listed companies in the food industry. Investment Management and Financial Innovations, 13(2), 29-41.

Rogova, E. (2014). DuPont analysis of the efficiency and investment appeal of Russian oil-extracting companies: $8^{\text {th }}$ International Scientific Conference. Business and Management, Vilnius, Lithuania. Available at http://www.bm.vgtu.it

Sheela, C. S., \& Karthikeyan, K. (2012). Financial performance of the pharmaceutical industry in India using DuPont analysis. European Journal of Business and Management, 4 (14). Available at: http://www.iiste.org.

Soliman, M. T. (2008). The use of DuPont analysis by market participants. The Accounting Review, 83(3), 823-853.

Tushar, S. (2017). Return on equity analysis using the DuPont model. International Journal of Advanced Research 5(8), pp. 1504-1508 
Yang, S. P., \& Yoon, D. S. (2005). The impacts of financial characteristics on profitability performances in foodservice companies. Journal of Food Service Management, 8(1), 273-293.

$--0--$

\section{How to Cite this Article}

Ahamed, M. J. (2020). Comparison of the Financial Performance between Square Pharmaceuticals Limited and Beximco Pharmaceuticals Limited: DuPont Analysis. Global Disclosure of Economics and Business, 9(1), 39-48. https://doi.org/10.18034/gdeb.v9i1.506 